\title{
Community structure and condition of seagrass meadows in Ayau Islands, Raja Ampat Regency
}

\author{
Andri Irawan ${ }^{1,}$ *, Muhammad Hafizt ${ }^{2}$, Udhi Eko Hernawan ${ }^{2}$ \\ ${ }^{1}$ Research Center for Deep Sea, Indonesian Institute of Sciences, Jl. Y. Syaranamual, Poka, Ambon, Indonesia \\ ${ }^{2}$ Research Center for Oceanography, Indonesian Institute of Sciences, JI. Pasir Putih I, Ancol Timur, Jakarta Utara, Indonesia
}

\begin{abstract}
ARTICLE INFO
ABSTRACT

Article history:

Submitted 11 January 2020

$1^{\text {st }}$ Revision 20 February 2020

$2^{\text {nd }}$ Revision 2 April 2020

Accepted 21 July 2020

Published online 31 July 2020

\section{Keywords:}

seagrass

outer island

expedition

baseline information

status

Seagrass meadows are an important component of coastal ecosystems, providing many ecosystem services beneficial for human well-being. Basic information about seagrass meadows in Indonesia is relatively limited, particularly in the eastern part of Indonesia, such as the remote Ayau Islands in Raja Ampat. In this paper, we reported the community structure and condition of seagrass meadows in Ayau Islands surveyed during Nusa Manggala Expedition in November 2018. We conducted the seagrass survey using quadrat transect method at five locations, i.e. Reni, Rutum, Abidon, Kanober, and Dorehkar. In the survey, we assessed parameters of community structure, including habitat extent, species composition, seagrass cover, seagrass density, macroalgae and epiphyte cover. We also recorded environmental parameters, i.e. substrate types, water clarity, salinity, water temperature, and nutrient (phosphate and nitrate). Our study showed that seagrass meadows in Ayau Islands are multispecies meadows, composed of two to five species. In overall, five species recorded in Ayau Islands are Cymodocea rotundata, Enhalus acoroides, Halodule pinifolia, Halophila ovalis, and Thalassia hemprichii. The most common species is T. hemprichii as it can be found in all locations. Meadows in Reni, Rutum, and Dorehkar are in a healthy condition, while in Abidon and Kanober are in less healthy condition. This information is of significance as baseline information needed for seagrass conservation planning.
\end{abstract}

C2020 Indonesian Institute of Sciences (LIPI).

\section{Introduction}

Seagrasses are flowering plant adapted to live underwater in the marine environment. These plants grow covering extensive areas of the seafloor, called as seagrass meadows. Their morphology resembles common terrestrial grasses with true leaves, rhizomes, roots, flowers and fruits (Brazier, 1975; Susetiono, 2004), which distinguished them with seaweeds, as seaweeds do not have those organs. Seagrass meadows play important ecological roles in the shallow waters of tropical and temperate coasts (Dawes, 1981). Seagrass canopy structure and root system have a large influence on sedimentation and ecology of shallow habitats (Brazier, 1975). The meadows support a great variety of marine animals. They provide habitat for sea mammals, benthic organisms, and fishes, some of which are commercially

\footnotetext{
${ }^{*}$ Corresponding Author

A. Irawan: andri.irawan@lipi.go.id
}

important species. Some species use seagrass meadows for spawning and nursery ground, and shelter/protection from predators. Seagrasses are primary producers, which serve as the foundation of the food web (de Boer, 2007). Furthermore, seagrass meadows help mitigate climate change because they absorb carbon dioxide dissolved in seawater (Fourqurean, et al., 2012)

As an archipelagic country, Indonesia's coastline is one of the longest in the world. Consequently, Indonesia is is blessed with vast coastal areas, and these areas are rich with diverse coastal ecosystems, such as seagrass meadows. Although seagrass habitat in Indonesia is potentially the largest in the world, our knowledge on seagrasses in Indonesia is relatively limited, compared to mangroves and coral reefs that have received more scientific attention. Furthermore, for many remote locations in the eastern parts of Indonesia, such as Ayau Islands, Raja Ampat, basic information on seagrasses is even absent. Species composition, habitat extent, community structure, and condition of the seagrass 
meadows area still unknown in such locations (Supriyadi, et al., 2018), despite the fact that this area is part the Coral Triangle (Fortes, et al., 2018). Furthermore, in remote locations such as Ayau Island, accessibility and logistic problems might hamper a study to be held there (Fortes, et al., 2018). Most of the information about seagrass in this regency came from neighbouring bigger islands closer to the mainland, such as Waisai (Ausal, et al., 2017) and Salawati (Hoek, et al., 2016).

Thus, an expedition to reach this area was carried out in November 2018 using the Research Vessel Baruna Jaya VIII, which called Nusa Manggala Expedition 2018. In particular, this study assessed meadow' s characteristics, species composition and their distribution, and the status of the seagrass meadows in the islands.

\section{Materials and Methods}

The field study was conducted in November 2018 at five locations (Reni, Rutum, Abidon, Kanober, and Dorehkar (Figure 1). These locations were selected based on seagrass habitat representation interpreted from remote sensing of Google Earth imageries. At each location, data was collected using the quadrat transect method. Due to the limited time in the field and the main objective of the expedition was on diversity aspect, therefore a single line transect was laid perpendicular to the shore, started from the point where seagrasses were found to the final point seaward where seagrasses were no longer present. This transect length data also serve as ground truth data for satellite image analysis. For this purpose, the geographical position of each transect was determined and recorded by a GPS receiver. The additional transect was planned to laid if there was still time to do it. However, in practice the allocated time already consumed by the journey to find a save passage to reach the island by rubber boat from the vessel and also the traditional permission process to the local people.

On the transect, a 50x50cm-quadrat frame was placed at every $10 \mathrm{~m}$ intervals, and data on species composition, seagrass cover (total and per species), seagrass density, macroalgae and epiphyte cover inside the frame was determined and recorded. The seagrass, macroalgae and epiphyte cover refers to the seagrass cover standard from Seagrass-Watch (McKenzie, et al., 2003). Data of seagrass composition, cover and density were combined to calculate Important Value Index (IVI) for determining the dominant seagrass species in the seagrass meadows (Gopal \& Bhardwaj, 1979).

Additionally, we also measured environmental parameters directly in the location, i.e. substrate type, water clarity, salinity, water temperature, and nutrient (phosphate and nitrate). Dominant substrate type was determined by hand-touch as mud, sand, rubble, or a combination of two or three types. Water clarity was planned to be measured by a Secchi disk, however, the disk had already hit the bottom before can be unseen from the surface as the water clarity was quite clear. Therefore, quantitative data for water clarity is not available.

Due to limited personnel to handle physiochemical parameters and the lack of equipment, the measurement was done by simple equipment and test kit. Salinity was measured by using a refractometer. Water temperature was measured by using a thermometer. Phosphate and nitrate concentration was determined by using Sera ${ }^{\circledR}$ Phospate-Test and Sera ${ }^{\circledR}$ Nitrat-Test kit, that usually used

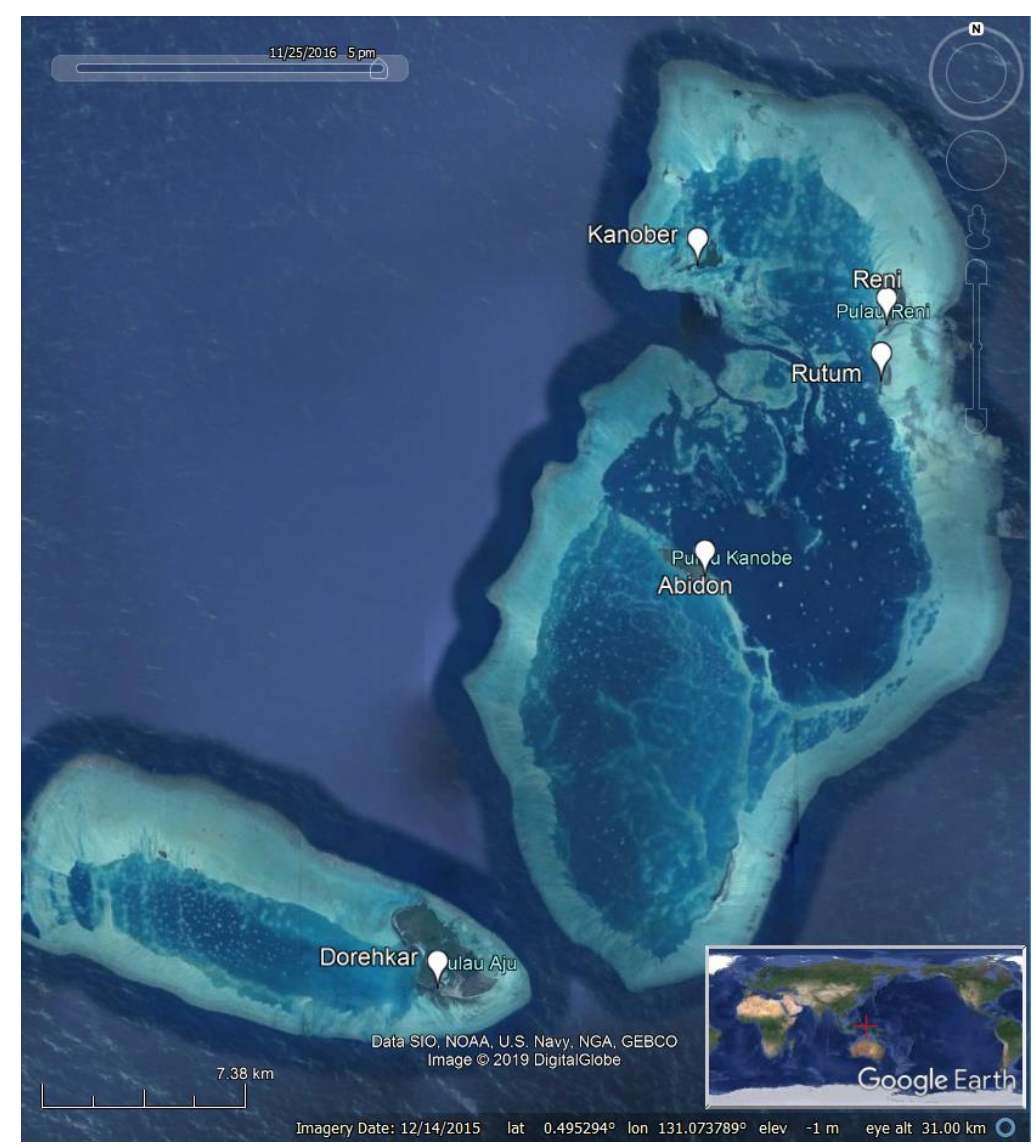

Figure 1. Research sites in Ayau Island which located at Kanober, Reni, Rutum, Abidon, and Dorehkar 
for aquarium testing. The phosphate test kit have a reading range from $0.1-10.0 \mathrm{mg} / \mathrm{l}$, meanwhile the nitrate test kit have a reading range from 0 to $>100 \mathrm{mg} / \mathrm{l}$. However, as both are simple test kit, detailed reading could not be gained because these kits show a group of value range than unit value. For example, for nitrate analysis, the result will appear as a colour of solution that corresponds to the value of $0,25,50$, or $>100 \mathrm{mg} / \mathrm{l}$.

Seagrass area was obtained from satellite image analysis of Planet Dove imagery (3-meter spatial resolution and visible-NIR bands) (Marshall, et al., 2017), which suitable to map detailed information in a large area like Ayau Islands. In addition, the visible bands are essential to identify seagrass cover under the waters (Green, et al., 2000). The analysis was conducted by following the guideline to map benthic habitat, which included seagrass cover in it (Green, et al., 2000; Rahmawati, et al., 2019). Regarding the guideline, image correction and image classification was applied before calculating the seagrass area. Image correction consisting of sun glint correction (Kay, et al., 2009) and water column correction using Depth Invariant Index Model (Hafizt, et al., 2017a; Hafizt, et al., 2017b), while image classification used ISO-DATA algorithm (Green, et al., 2000). The next step is converting raster to vector in order geometry calculation can be proceeded.

Meadow's characteristics of each location are based on the length of seagrass meadows from the beach to the sea, and also the area size. Other parameters for the characteristics consist of the depth, seagrass and macroalgae cover along the transect, water clarity, substrate type, seagrass composition, and dominant seagrass in each location.
Seagrass species composition and their distribution are determined by the result of on-field observation inside the quadrat. The identification to species level was strengthened by further examination of the samples in laboratory facility of RV Baruna Jaya VIII using several references (Azkab, 1999; Menez, et al., 1983; den Hartog, 1970; den Hartog \& Kuo, 2006).

Status of the seagrass meadows in the islands determined mainly by their canopy cover average in each location, which refers to the standard value from the Indonesian Ministry of Environment to determine seagrass meadows condition. In this ministerial decree (KMNLHRI, 2004), there are three categories of seagrass meadows condition based on their canopy cover, which are: rich/healthy (cover $\geq 60 \%$ ), less rich/less healthy (cover $30-59.9 \%$ ) and poor (cover $\leq 29.9 \%$ ). Although there is a lot of criticism about this standard and there is an effort to propose a new standard which covers more parameters, at the moment this decree is the legal standard which applied in Indonesia.

\section{Results}

\subsection{Characteristic of each location}

\subsubsection{Reni Island}

Reni Island is located in the northeast part of Ayau Islands. The length of the island is approximately $2 \mathrm{~km}$ from north to south and $650 \mathrm{~m}$ from west to east. The settlements are concentrated in the southern part of this island, occupying a third area of the island. According to the satellite image, the seagrass meadows are mostly located on the southern side of this island, so the observation transect was located there (Figure 2).

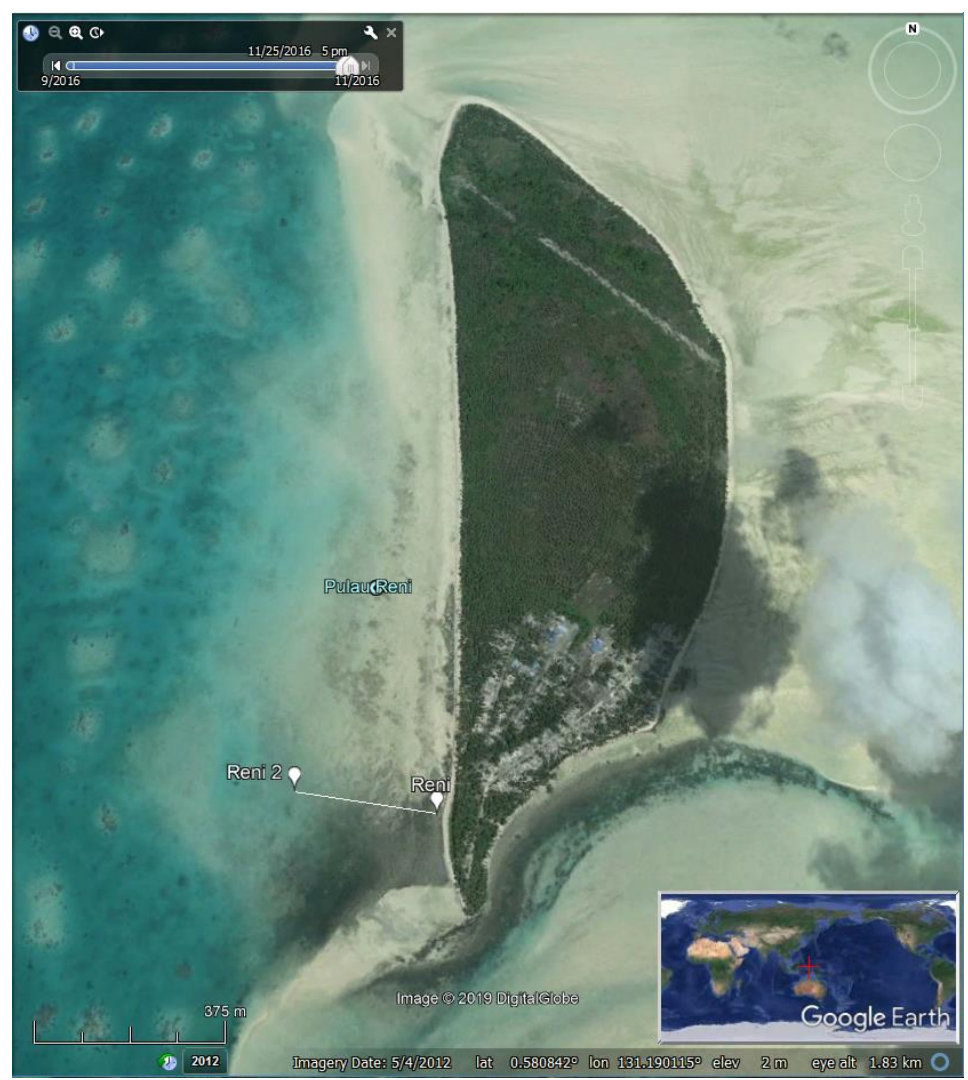

Figure 2. Transect placement (white line) in Reni Island, with a length of $310 \mathrm{~m}$. The line started at N $0.57551 \mathrm{E} 131.18916$ and finished at N $0.57595 \mathrm{~T} 131.18643$ 
The seagrass meadow extends around $310 \mathrm{~m}$ from the shore to the sea, with depth varied from 10 to $120 \mathrm{~cm}$ (Table 1). In the first and last $80 \mathrm{~m}$ of the transect, the seagrass cover fluctuates between 50 to $90 \%$ accompanied by seaweed vegetation with maximum cover $30 \%$. In contrast, in the middle of the transect, the seagrass cover remains steady at $70 \%$, with a small peak on the 150 meters at $90 \%$. In this part of the transect, the macroalgae cover is ranged from 0 to $25 \%$ (Figure 3 ). Overall, the seagrass meadows in Reni Island is considered as healthy because the average canopy cover is $71 \%$ (Table 1 ).

The meadow on this island has a clear water condition and the substrate mostly in the form of sand (Table 1 ). Analysis of satellite imagery and ground truth data shows that the seagrass meadow occupies $163,944 \mathrm{~m}^{2}$ of the coastal area of this island, which composed of Cymodocea rotundata and Thalassia hemprichii (Table 1). Based on Important Value Index calculation, T. hemprichii value is the largest than the other, which make this species as the dominant species in this location.

\subsubsection{Rutum Island}

Rutum Island is located in the northeast part of the Ayau Islands. The length of the island is approximately $900 \mathrm{~m}$ from north to south and $350 \mathrm{~m}$ from west to east. The settlements are situated in several areas of this island in north to south direction with an area of half of the island. Based on the satellite image, the seagrass bed is larger on the west side of the island (Figure 4), so the observation transect was placed in this area.

The length of the seagrass bed from the beach to the sea was approximately $90 \mathrm{~m}$, with depth varied from 50

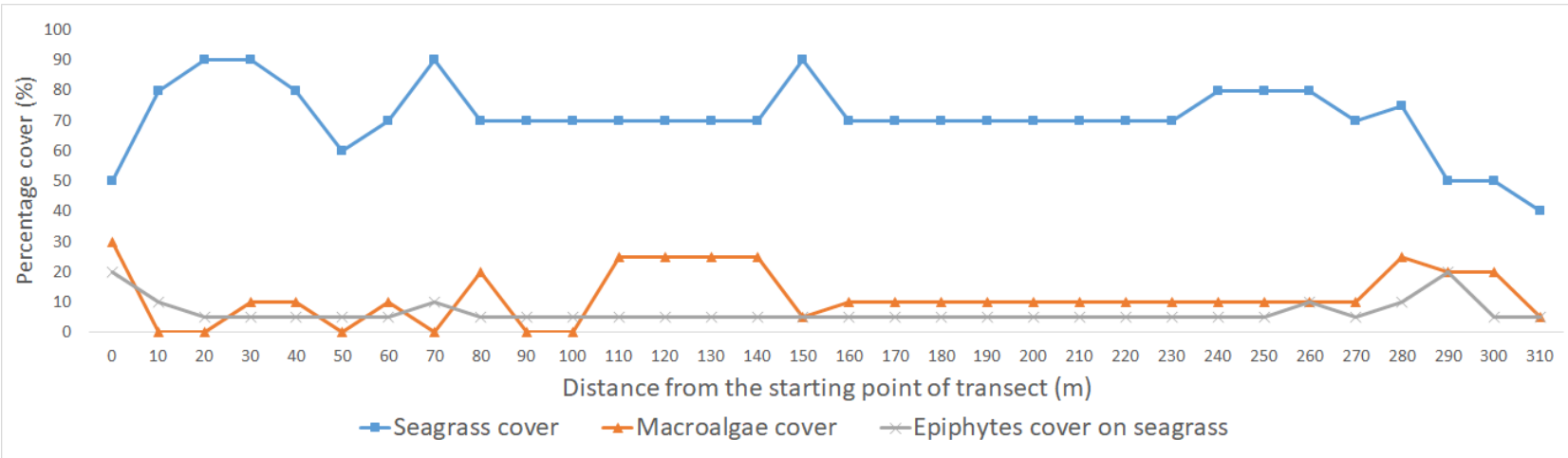

Figure 3. Dominant vegetation composition along the transect in Reni Island.

Table 1. Seagrass species distribution and seagrass meadow environmental and vegetation parameter of five locations in Ayau Islands

\begin{tabular}{|c|c|c|c|c|c|}
\hline & Reni & Rutum & Abidon & Kanober & Dorehkar \\
\hline \multicolumn{6}{|l|}{ Species } \\
\hline Halodule pinifolia & & $\mathrm{x}$ & $\mathrm{x}$ & & \\
\hline Cymodocea rotundata & $\mathrm{x}$ & $\mathrm{x}$ & $\mathrm{x}$ & & $\mathrm{x}$ \\
\hline Enhalus acoroides & & & & $\mathrm{x}$ & $\mathrm{x}$ \\
\hline Thalassia hemprichii & $\mathrm{x}$ & $\mathrm{x}$ & $\mathrm{x}$ & $\mathrm{x}$ & $\mathrm{x}$ \\
\hline Halophila ovalis & & & $\mathrm{x}$ & & $\mathrm{x}$ \\
\hline \multicolumn{6}{|l|}{ Environmental parameters } \\
\hline Dominant substrate & sand & sand & sand + rubble & sand & sand \\
\hline Water clarity & clear & clear & clear & clear & clear \\
\hline Water temperature $\left({ }^{\circ} \mathrm{C}\right)$ & 36 & 31 & 33 & 30 & 33 \\
\hline Salinity (\%o) & 35 & 34.5 & 34.5 & 33.5 & 35 \\
\hline Phosphate concentration (mg/L) & $<0.1$ & $<0.1$ & $<0.1$ & $<0.1$ & $<0.1$ \\
\hline Nitrate concentration (mg/L) & undetected & undetected & undetected & undetected & undetected \\
\hline \multicolumn{6}{|l|}{ Vegetation parameters } \\
\hline Meadows length (m) & 310 & 90 & 160 & 60 & $>600$ \\
\hline Meadows area $\left(\mathrm{m}^{2}\right)$ & 163944 & 139518 & 37593 & 4815 & 1367694 \\
\hline Meadows depth range $(\mathrm{cm})$ & $10-120$ & $50-255$ & $30-155$ & $120-270$ & $50-95$ \\
\hline $\begin{array}{l}\text { Seagrass density (mean } \pm \text { SD) } \\
\text { shoots } / \mathrm{m}^{2}\end{array}$ & $\begin{array}{l}716.00 \pm \\
201.03\end{array}$ & $\begin{array}{l}914.80 \pm \\
166.74\end{array}$ & $\begin{array}{l}495.06 \pm \\
71.24\end{array}$ & $\begin{array}{c}108.00 \pm \\
21.71\end{array}$ & $\begin{array}{l}596.26 \pm \\
152.16\end{array}$ \\
\hline Seagrass cover (mean \pm SD) $(\%)$ & $71.09 \pm 11.57$ & $64.00 \pm 15.45$ & $30.00 \pm 17.90$ & $44.29 \pm 15.91$ & $67.21 \pm 21.28$ \\
\hline Macroalgae cover (mean \pm SD) (\%) & $11.72 \pm 8.62$ & $5.50 \pm 7.23$ & $23.82 \pm 21.18$ & $0.00 \pm 0.00$ & $5 \pm 9.36$ \\
\hline Epiphyte cover (mean \pm SD) (\%) & $6.56 \pm 3.84$ & $6.50 \pm 2.29$ & $15.88 \pm 23.21$ & $11.43 \pm 11.86$ & $12.62 \pm 14.27$ \\
\hline Meadows statuses & Healthy & Healthy & Less healthy & Less healthy & Healthy \\
\hline Dominant seagrass (IVI) & Th & Th & Th & Ea & Th \\
\hline
\end{tabular}


to $255 \mathrm{~cm}$ (Table 1). The seagrass cover is gradually decreasing along the transect from $70 \%$ to $40 \%$ with a moderate fluctuation from 0 to the $60^{\text {th }}$ meter (Figure 5). Meanwhile, macroalgae coverage is mostly less than $10 \%$, except at the $30^{\text {th }}$ meter of the transect. Overall, the seagrass meadows could be considered as healthy because the canopy cover has the average at 64\% (Table 1).

The meadow on this island has a clear water condition and the substrate mostly in the form of sand (Table 1). Analysis of satellite imagery and ground truth data shows that the seagrass meadow occupies $139,518 \mathrm{~m}^{2}$ of the coastal area in this island, which composed of Halodule pinifolia, Cymodocea rotundata and Thalassia hemprichii (Table 1). Based on IVI calculation, the largest value belongs to $T$. hemprichii, making this species as the dominant seagrass in this location.

\subsubsection{Abidon}

Abidon is located at the centre of Ayau Island. The length of the island is approximately $2 \mathrm{~km}$ from northwest to southeast and $600 \mathrm{~m}$ from southwest to northeast. Local settlements are concentrated only in the southeast part of the island with an area of approximately $10-15 \%$ of the island. There are two long piers stretching out from the settlement to the deeper waters.

Based on the satellite image, seagrasses grow surrounding the island but covering a narrow band in the intertidal areas. The longest length of seagrass located in the southern part of the island (Figure 6), so the observation transect was placed there. There are no rivers nor mangroves in this location. In addition, there was a lot of boat traffic in the seagrass area when the observations was taking place.

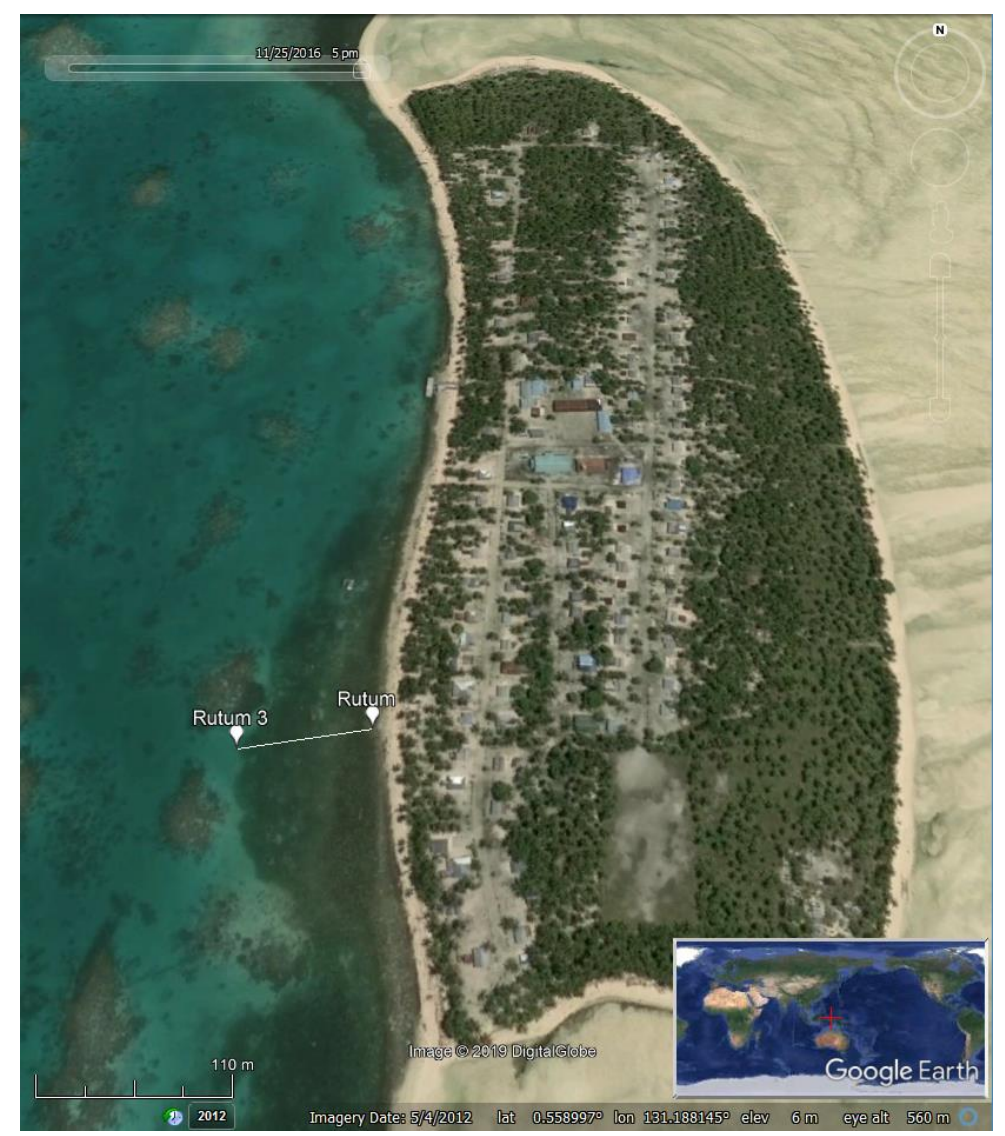

Figure 4. Transect placement location (white line) in Rutum Island. The length of the transect was $90 \mathrm{~m}$, started from the beach at $\mathrm{N} 0.55794 \mathrm{E} 131.18736$ and finished in the sea at N $0.55783 \mathrm{E} 131.18655$

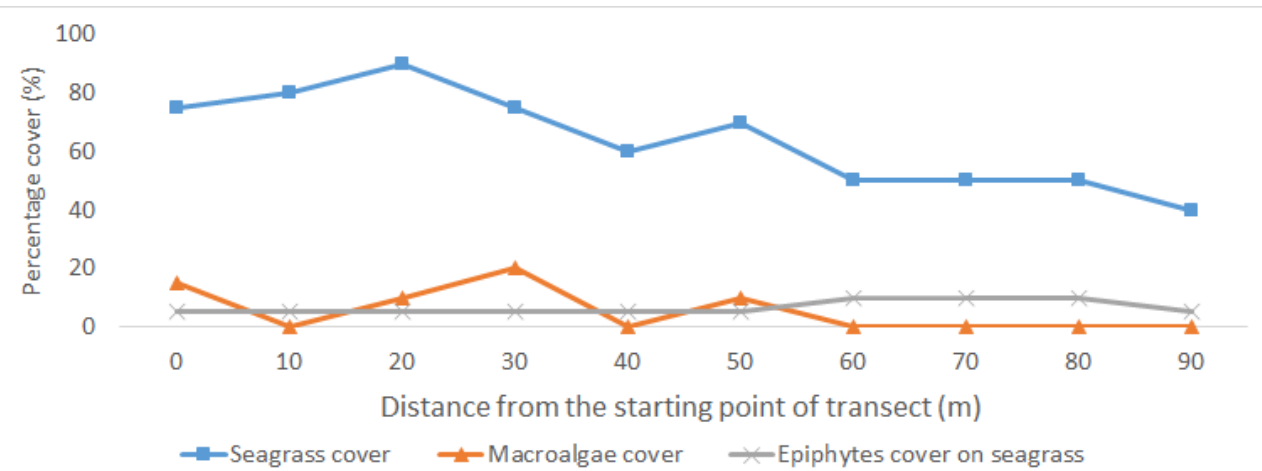

Figure 5. Dominant vegetation composition along the transect in Rutum Island 
The seagrass bed in the south of the island stretched $160 \mathrm{~m}$ from the coast to the sea, with depth varied from 30 to $155 \mathrm{~cm}$ (Figure 7, Table 1). In the first 70 meters, the seagrass cover increases gradually from 20 to $70 \%$ with some fluctuations. Seagrass in this area is accompanied by seaweed vegetation up to $50 \%$. For the next 70 meters, the seagrass cover drop to less than $10 \%$, which started by a dramatic decline in 70th to 80th meter and levelling off until the 120 meters at around $20 \%$ with a dip around the $100 \mathrm{~m}$ at $15 \%$. From this point, the seagrass cover drops to less than $15 \%$ towards the end of the transect, with a peak of $30 \%$ on the last 10 meters. On the contrary, the seaweed cover is increasing dramatically from 0 to $50 \%$ in the second 70 -meter area before drops again to around $10 \%$ in the last 40 meters. Overall, the seagrass meadows in Abidon could be considered as less healthy because the canopy cover has an average of 30\% (Table 1).

The meadow on this island has a clear water condition and the substrate mostly in the form of mix sand and rubble (Table 1 ). Analysis of satellite imagery and ground truth data shows that the seagrass meadow occupies $37,593 \mathrm{~m}^{2}$ of the coastal area in this island, which consisted of Halodule pinifolia, Cymodocea rotundata, Thalassia hemprichii, and Halophila ovalis. According to the IVI calculation, T. hemprichii is the most dominant species in this location (Table 1 ).

\subsubsection{Kanober}

Kanober is located in the north part of the Ayau Islands. The length of the island is approximately $1.7 \mathrm{~km}$ from west to east and almost $1 \mathrm{~km}$ from north to south. There is no settlement on this island. According to the satellite images, seagrass is growing along the coast, and the vast meadow located in several bays of this island (Figure 8), so the observation transect was placed in one of the bay.

The seagrass bed in Kanober stretched about $60 \mathrm{~m}$ from the beach to the sea (Figure 9), with depth varied from 120 to $270 \mathrm{~cm}$ (Table 1 ). The seagrass cover increases sharply from 25 to $50 \%$ in the first 10 meters and continued with a slight increase to $60 \%$ for the next 40

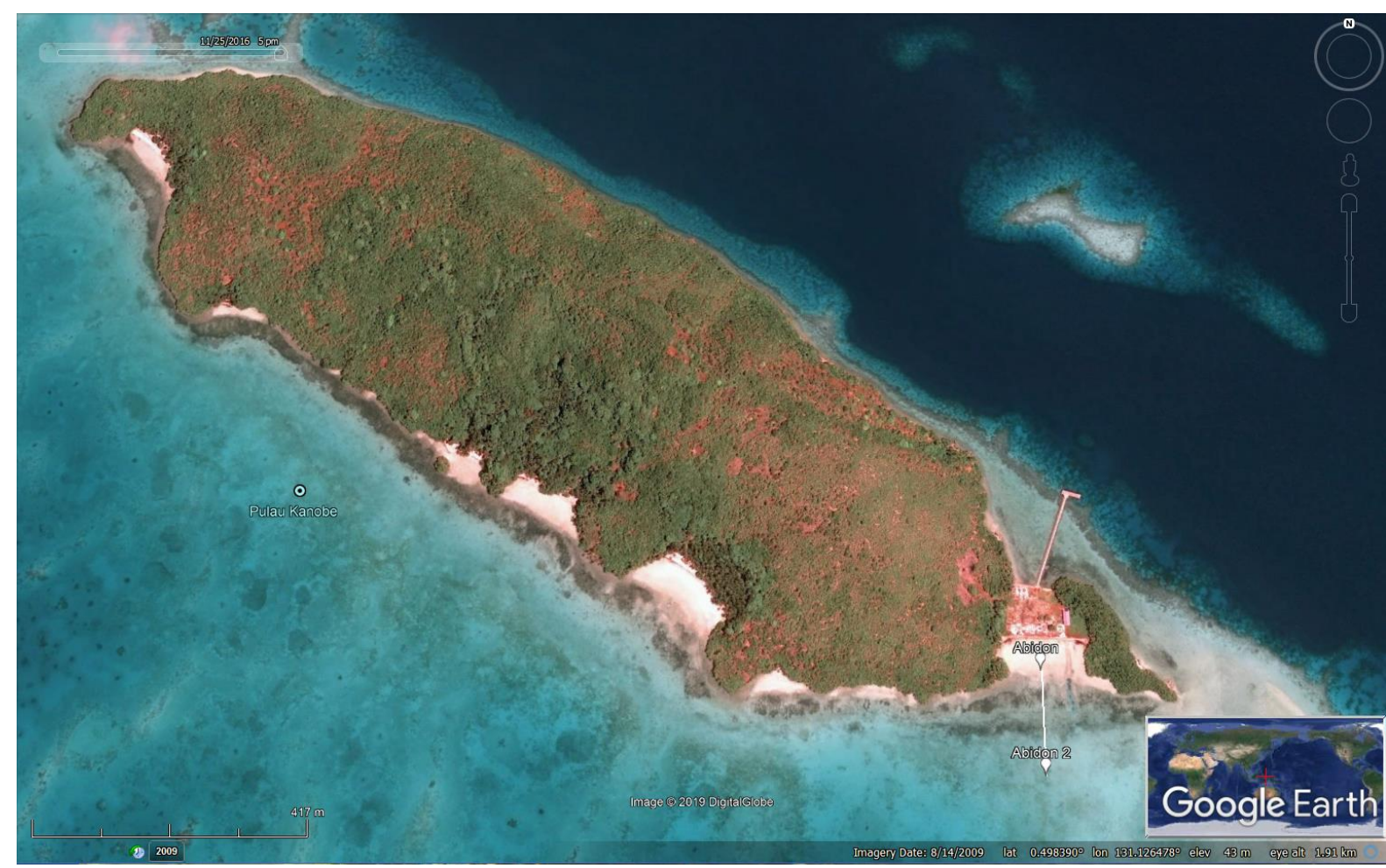

Figure 6. Transect placement location (white line) in Abidon. The length of the transect is $160 \mathrm{~m}$, started at N $0.49505 \mathrm{E}$ 131.13127 and finished at N 0.49361 E 131.13124

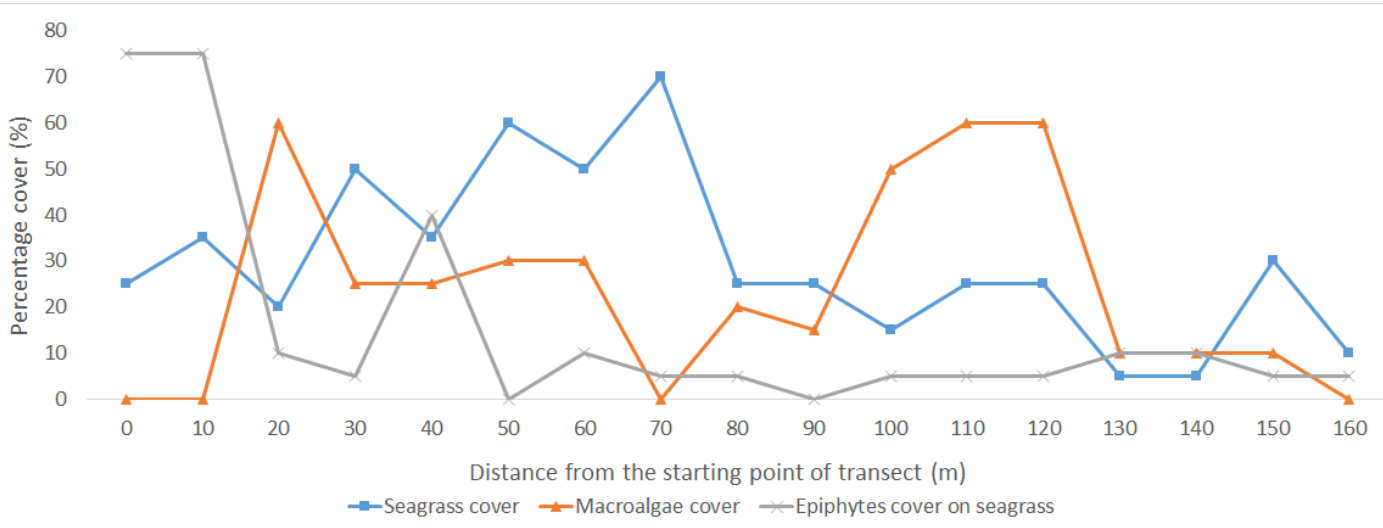

Figure 7. Dominant vegetation composition along the transect in Abidon 
meters to the sea. From this point, the seagrass cover is decreasing dramatically to around $15 \%$ in the last 10 meters. Overall, the seagrass condition in Kanober could be considered as moderate (less healthy) status because the average of canopy cover is $44 \%$ (Table 1 ).

The meadow on this island has a clear water condition and the substrate mostly in the form of sand (Table 1). Analysis of satellite imagery and ground truth data shows that the seagrass meadow occupies $4,815 \mathrm{~m}^{2}$ of the coastal area on this island, which composed of Enhalus acoroides and Thalassia hemprichii. The first species is the dominant species due to the larger IVI value than the other one (Table 1).

\subsubsection{Dorehkar}

Dorehkar is located in the south part of Ayau Island and being the largest island of this area. The length of the island is approximately $4 \mathrm{~km}$ from northwest to southeast and $2 \mathrm{~km}$ from southwest to northeast. There are several groups of settlements on the west and south coast of the island, with the largest one located in the south part of the island near the lagoon. Based on the satellite image, the seagrass bed is situated in the western and southern parts of the island. Because the southern part has a larger size, so the transect was placed there (Figure 10).

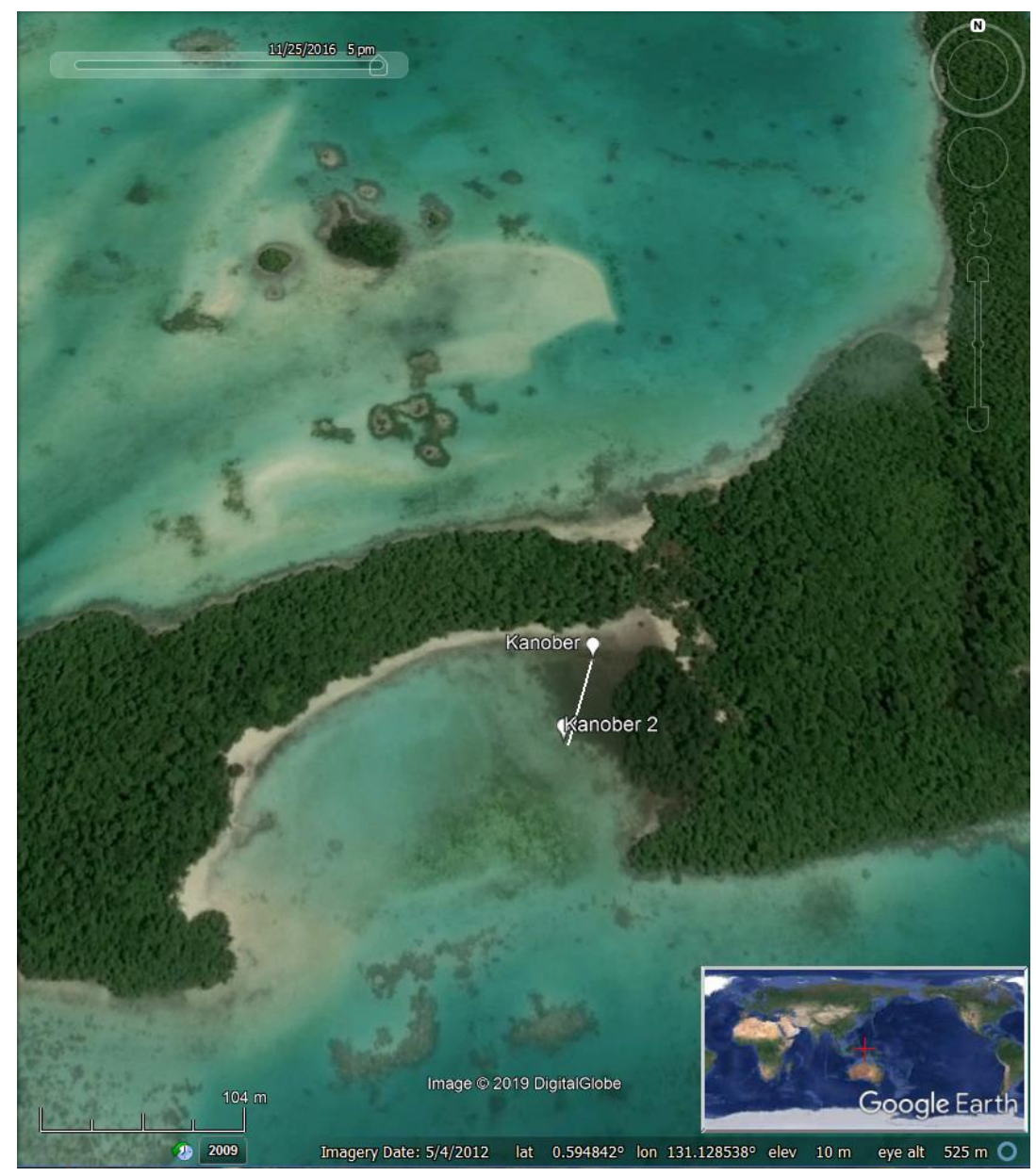

Figure 8. Transect placement location (white line) in Kanober. The length of the transect is $60 \mathrm{~m}$, which started at N 0.59438 TE131.12892 and finished at N 0.59392 E 131.12875

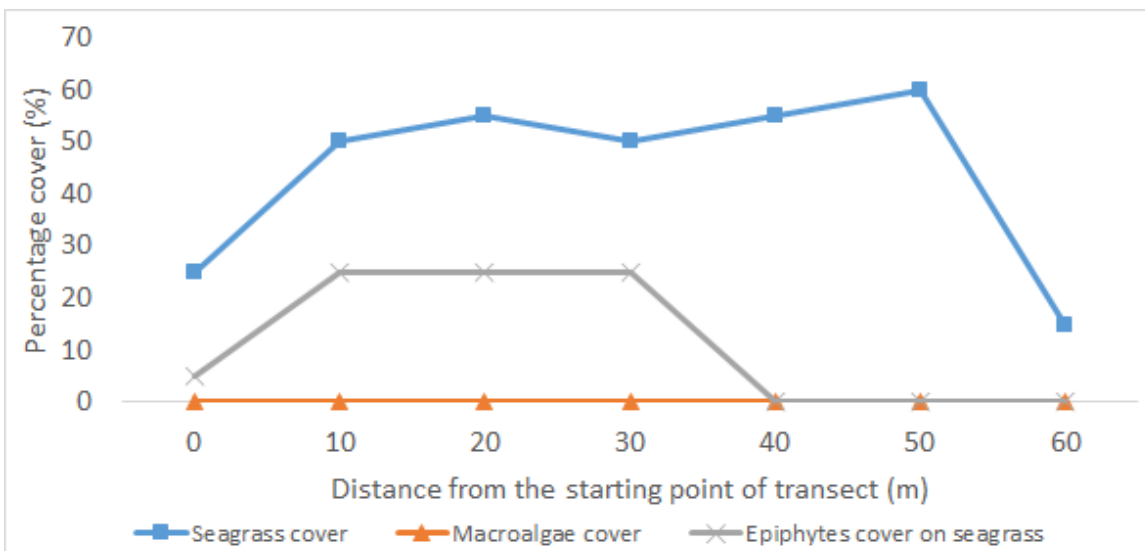

Figure 9. Dominant vegetation composition along the observation transect in Kanober 
Seagrass bed in Dorehkar stretch more than $600 \mathrm{~m}$ from the coastline to the sea; however, due to the time allocation in the field, we just finished the survey at $600 \mathrm{~m}$ of the transect (Figure 11). In the first half of the transect, the seagrass cover fluctuates wildly, with the range from 50 to $95 \%$. There were some seaweed patches in this area, with the cover around $10 \%$. For the next half of the transect, the seagrass cover is gradually decreasing from 80 to $15 \%$ at the end of the transect. In the last 100 meters, seaweed vegetation is more dominant to seagrass, with the cover ranges from 10 to $40 \%$. Overall, the seagrass meadow status in Dorehkar is considered as healthy because the average canopy cover is $67 \%$ (Table 1 ).

The meadow on this island has a clear water condition and the substrate mostly in the form of sand, with depth varies from 50 to $95 \mathrm{~cm}$ (Table 1). Analysis of satellite imagery and ground truth data shows that the seagrass meadow occupies 1,3 million square meters of the coastal area on this island. Four seagrasses present at the meadows in Dorehkar, which are Cymodocea rotundata, Halophila ovalis, Enhalus acoroides, and Thalassia hemprichii. According to the IVI measurement (Table 1), $T$. hemprichii has the highest value, which made this species as the most dominant species in this location.

\subsection{Seagrass composition and distribution}

There are five seagrass species found from five locations in these islands. The species are Halodule pinifolia (Miki) den Hartog, Cymodocea rotundata Ehrenberg \& Hemprich, ex Ascherson, Enhalus acoroides

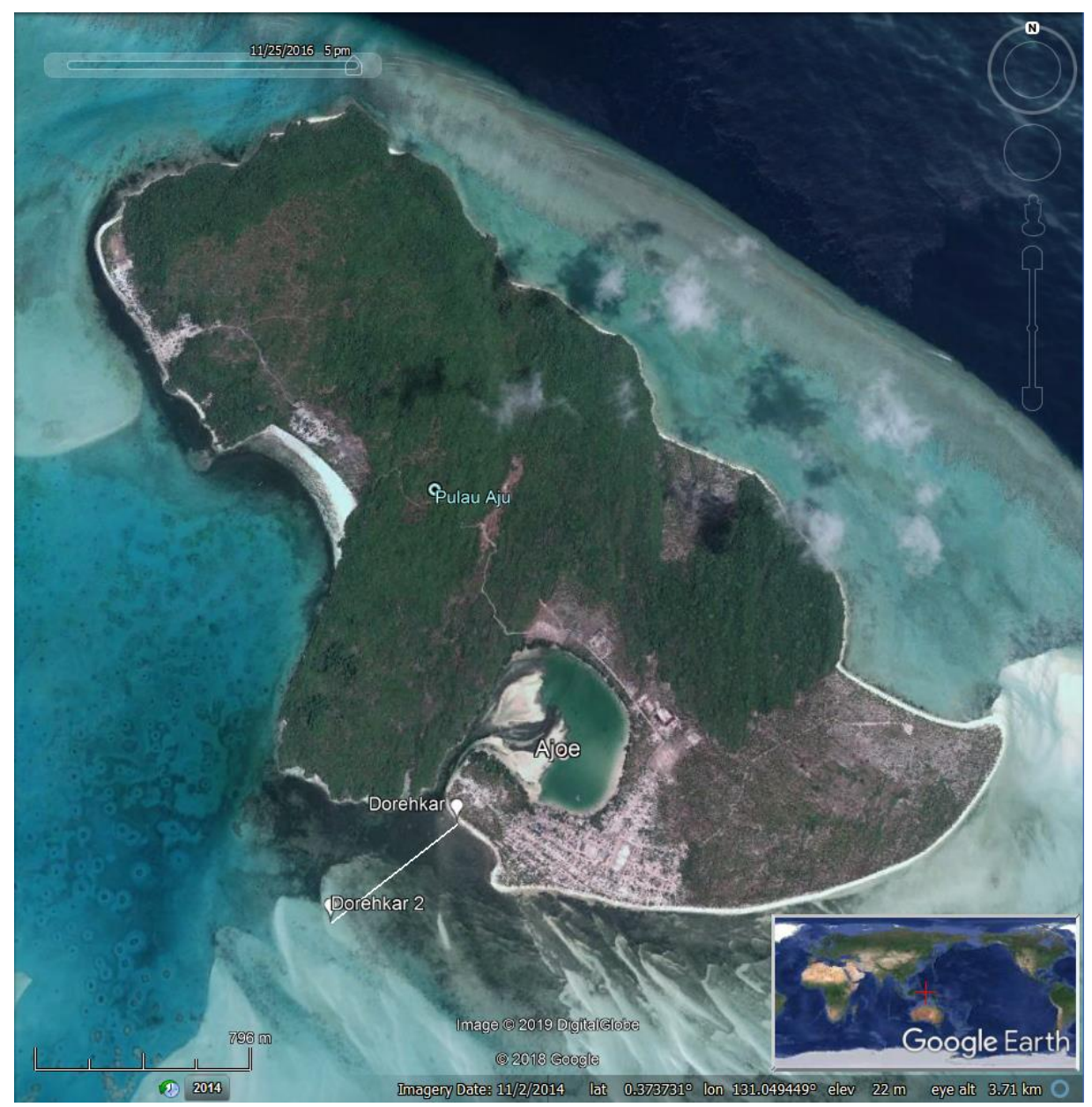

Figure 10. Transect placement location (white line) in Dorehkar. The length of the transect was $600 \mathrm{~m}$, which started at N 0.36441 E 131.04628 and finished at N 0.36110 E 131.04201

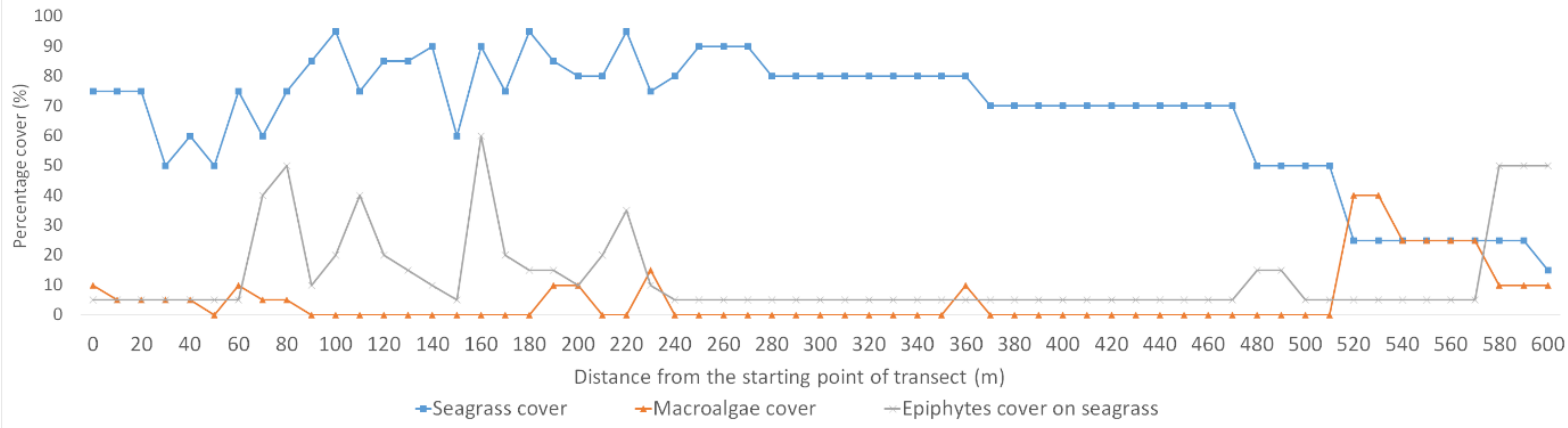

Figure 11. Dominant vegetation composition along the observation transect in Dorehkar 

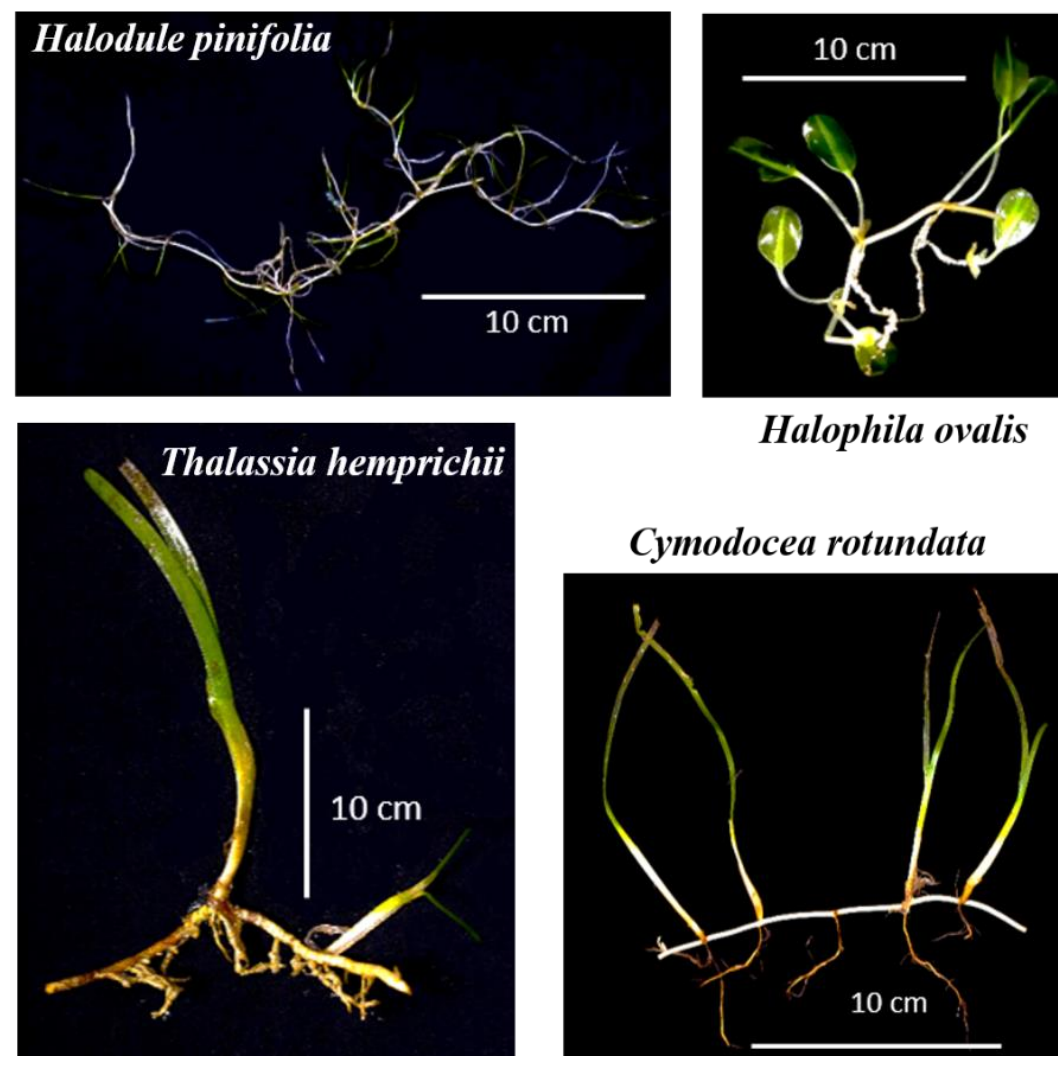

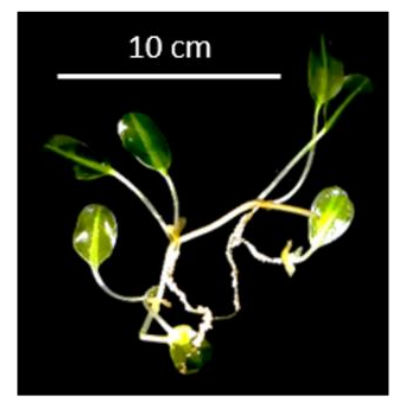

Halophila ovalis

Figure 12. Five seagrasses found in this expedition: Halodule pinifolia (Miki) den Hartog, Cymodocea rotundata Ehrenberg \& Hemprich, ex Ascherson, Thalassia hemprichii (Ehrenberg) Ascherson, Enhalus acoroides(Linn. f.) Royle, Halophila ovalis (R. Brown) Hooker f. Photos taken by Bronto (Media Indonesia).

(Linn. f.) Royle, Thalassia hemprichii (Ehrenberg) Ascherson, and Halophila ovalis (R. Brown) Hooker f. (Figure 12). Of all these species, only $T$. hemprichii can be found in all locations, whereas other species distributed differently (Table 1). With respect to species richness, Abidon and Dorehkar have the highest number of species (four species) compared to the other locations.

\subsection{Condition of the seagrass meadows}

\subsubsection{Density}

The location with the highest seagrass density is in Rutum at 915 shoots $/ \mathrm{m}^{2}$, and the lowest is in Kanober at 108 shoots $/ \mathrm{m}^{2}$ (Table 1 ). Overall, most of the locations have seagrass density of more than 400 shoots $/ \mathrm{m}^{2}$, which are 716 shoots $/ \mathrm{m}^{2}$ (Reni), 596 shoots $/ \mathrm{m}^{2}$ (Dorehkar) and 495 shoots $/ \mathrm{m}^{2}$ (Rutum). However, due to different morphology of seagrass species, this density value is not suitable as an indicator of seagrass condition. In Indonesia, the status of seagrass meadows is determined by their canopy cover value (KMNLHRI, 2004).

\subsubsection{Canopy cover}

The highest seagrass canopy cover is observed in Reni, with an average of $71 \%$, and the lowest is in Abidon at 30\% (Table 1 ). The remaining stations have a mean seagrass cover at 67\% (Dorehkar), 64\% (Rutum) and 44\% (Kanober). This canopy cover value have made the seagrass statuses in Reni dan Rutum categorized as healthy due to the cover is larger than 60\%, and likely so in Dorehkar. Meanwhile, seagrass meadows in Abidon and Kanober have a status of less health because the seagrass covers are in the range of $30-60 \%$ (Table 1 ). In overall, from the average cover value of the five locations, which is at 55\%, it is suggested that the status of the seagrass bed in Ayau Island is less health.

\subsubsection{Dominant seagrass}

In vegetation study, the dominant species cannot be defined merely from one aspect, such as the highest density, cover, or frequency. All of the aspects should be combined, which form an index of the important value (IVI) of each species (Gopal \& Bhardwaj, 1979). Based on the calculation of that index, the dominant seagrass species in Ayau Islands is Thalassia hemprichii because its IVI was the highest in four of five locations (Table 1). The only location that this species not dominant was in Kanober because it's IVI is lower than Enhalus acoroides value.

\subsubsection{Environmental characteristics}

Environmental conditions at the field sampling period were relatively similar in all locations. The first parameter is the dominant substrate which mostly in the form of sand, except in Abidon. The second parameter is water clarity which mostly in clear condition. The third parameter is temperature, which ranged at $30-36{ }^{\circ} \mathrm{C}$. The fourth parameter is salinity, which ranged at 33.5 - 35 per mile (\%). The fifth parameter is nutrients concentration, which is very low with phosphate less than $0.1 \mathrm{mg} / \mathrm{L}$, and nitrate level is undetected by the test kit that used in this research (Table 1 ). Almost all nitrate analysis shows a pale yellow colour of the solution, which are brighter than yellow ( $0 \mathrm{mg} / \mathrm{l})$ as the lowest standard. As the standards are gradually darkened from yellow to brown as nitrate concentration increasing, there is no other explanation on the manual of the kit for pale yellow results. 


\section{Discussions}

The species number of seagrasses in this study (five species) is relatively low compared to several nearby locations (Table 2). In other locations of Raja Ampat Regency, such as in Waisai and North Salawati there are seven seagrasses observed although with different composition in each location (Hoek, et al., 2016; Ausal, et al., 2017), which mean that more than five seagrasses can grow in this regency. If this data compared to further locations such as in Biak, in Papua Province and also Ternate and Weda Bay, in North Maluku Province then the gap becomes wider because there are eight to nine species in those areas (Irawan, 2014; Ramili, et al., 2018). The apparent differences in the Ayau area compared to other locations are on the geographical aspect of the area that is more exposed to the ocean than the other locations and the size of the island that smaller. This condition might reduce the protection of the seagrass from the wave. Another possible factor might because there is a limited dispersal pathway between meadows (Fortes, et al., 2018) in Ayau and the greater Raja Ampat Islands.

Among the five species of seagrasses found on this island, Thalassia hemprichii is dominant in four out of five stations (Table 1 ). The dominance of $T$. hemprichii in a seagrass bed is a common finding in Indonesia as the result of monitoring from 110 locations could confirm that fact, with this species dominate in most of the location (Sjafrie, et al., 2018), also in South East Asia (Fortes, et al., 2018). This dominance could be related to the cosmopolitan feature of this species, which can grow in a wide range of substrate and depth, especially in the intertidal tropical sandy beaches.

Besides seagrass species number, the density of seagrasses is an important property that affecting the condition of the seagrass meadows. The range of the seagrass density in Ayau Island is at $108-915$ shoots $/ \mathrm{m}^{2}$. This range is wider than the data from Salawati which is still in the same regency with Ayau at 280 - 391 shoots $/ \mathrm{m}^{2}$ (Hoek, et al., 2016). Seagrass density in Ayau Island is at a similar range with the seagrass density in Biak at 450 898 shoots $/ \mathrm{m}^{2}$ (Dewi, et al., 2017). Both locations have the same characteristic as an island with more directly expose to the Pacific Ocean than Salawati. However, this relation still needs to be studied further.
Regarding the low seagrass density in Kanober compared to the other locations, it could be related to the type of vegetation that composed by relatively large seagrasses, which are Enhalus acoroides and Thalassia hemprichii. With their large size, they cannot occupy an area with a large number of shoots compared to the smaller seagrasses such as Halodule pinifolia which grows in Rutum. However, this condition does not apply for Abidon, which has a density only at half from Rutum where bigger seagrass grows there. The possible reason could be related to the difference of substrate between both locations. In Abidon, the dominant substrate was a combination of sand and rubble (Table 1) compared to only sand in Rutum. Although more diversification of substrate may lead to more diversity of seagrasses, they usually do not grow well in the rubble type of substrate.

Another feature that forms a seagrass meadow condition is seagrass cover. The range of seagrass cover in Ayau Island is at $30-71 \%$. According to the regulation in Indonesia this value can be considered as less healthy to a healthy status of seagrass bed, with three of five stations are at healthy status (Table 1). This condition resembles the general condition of seagrass meadows in the eastern part of Indonesia which half of them are healthy and most of the other half are less healthy (Supriyadi, et al., 2018). Nevertheless, the maximum seagrass cover in this Ayau Island is lower than its neighbours, such as $80 \%$ in Biak (Dewi, et al., 2017) and 97\% in Salawati (Hoek, et al., 2016). So, regular monitoring is needed to gather more information about the future trend of the seagrass cover.

It is assumed that the higher the density, the higher the canopy cover. However, it might not always be true, particularly for different seagrass beds. In this study, the highest canopy cover was not found in Rutum, which has the highest density, and the lowest was not found in Kanober. In fact, the highest seagrass cover was in Reni, with an average of $71 \%$, and the lowest was in Abidon at $30 \%$. The low seagrass cover in Abidon was possibly related to the rubble content that mixed with sand substrates and the relatively higher macroalgae and epiphyte cover in this location than the other locations. This condition indicates a competition of the three marine plants (seagrasses-seaweeds / macroalgae-epiphytes) in these locations, which may affect to the seagrass cover as the indicator for the health status of the meadows.

Table 2. Comparison of species composition in nearby areas

\begin{tabular}{|c|c|c|c|c|c|c|}
\hline \multirow[b]{2}{*}{ Species } & \multicolumn{6}{|c|}{ Location } \\
\hline & $\begin{array}{l}\text { Ayau } \\
\text { (This } \\
\text { study) }\end{array}$ & $\begin{array}{c}\text { Waisai } \\
\text { (Ausal, et al., } \\
\text { 2017) }\end{array}$ & $\begin{array}{c}\text { North Salawati } \\
\text { (Hoek, et al., } \\
\text { 2016) }\end{array}$ & $\begin{array}{c}\text { Biak } \\
\text { (Dewi, et al., } \\
\text { 2017) }\end{array}$ & $\begin{array}{c}\text { Ternate area } \\
\text { (Ramili, et } \\
\text { al., 2018) }\end{array}$ & $\begin{array}{c}\text { Weda Bay } \\
\text { (Irawan, } \\
\text { 2014) }\end{array}$ \\
\hline Halodule uninervis & & & $\mathrm{X}$ & $\mathrm{X}$ & $\mathrm{X}$ & $\mathrm{X}$ \\
\hline Halodule pinifolia & $\mathrm{X}$ & $\mathrm{X}$ & $\mathrm{X}$ & $\mathrm{X}$ & & \\
\hline Cymodocea rotundata & $\mathrm{X}$ & $\mathrm{X}$ & $\mathrm{X}$ & $\mathrm{X}$ & $\mathrm{X}$ & $\mathrm{X}$ \\
\hline Cymodocea serrulata & & & $\mathrm{X}$ & $\mathrm{X}$ & $\mathrm{X}$ & $\mathrm{X}$ \\
\hline Syringodium isoetifolium & & $\mathrm{X}$ & $\mathrm{X}$ & & $\mathrm{X}$ & $\mathrm{X}$ \\
\hline Enhalus acoroides & $\mathrm{X}$ & $\mathrm{X}$ & $\mathrm{X}$ & $\mathrm{X}$ & $\mathrm{X}$ & $\mathrm{X}$ \\
\hline Thalassia hemprichii & $\mathrm{X}$ & $\mathrm{X}$ & $\mathrm{X}$ & $\mathrm{X}$ & $\mathrm{X}$ & $\mathrm{X}$ \\
\hline Halophila ovalis & $\mathrm{X}$ & $\mathrm{X}$ & $\mathrm{X}$ & $\mathrm{X}$ & $\mathrm{X}$ & $\mathrm{X}$ \\
\hline Halophila minor & & & & $\mathrm{X}$ & $\mathrm{X}$ & $\mathrm{X}$ \\
\hline Halophia spinulosa & & & & & $\mathrm{X}$ & \\
\hline Halophila decipiens & & $\mathrm{X}$ & & & & \\
\hline
\end{tabular}


Besides it cover, the good/healthy condition of the seagrass bed Reni, Rutum and Dorehkar can be seen from the proportion of seagrass cover to macroalgae cover, that is always bigger along the transect (Figure 3, Figure 5, and Figure 11. In addition, the epiphyte cover on seagrass leaves was mostly below $13 \%$, which might not disturb the seagrass' s leaves to receive sunlight for photosynthesis.

This relationship strengthened by the status of moderate (less healthy) in Abidon that might be related to the competition of source between seagrass and macroalgae. In this location, macroalgae cover was exceeding seagrass cover in some parts of the transect (Figure 7) and has an overall average at $24 \%$ (Table 1). In addition, epiphytes cover also reach $40 \%$ and $70 \%$ in several spots in the transect, indicating the increasing pressure on seagrasses.

However, unlike the other locations, the less healthy status in Kanober unlikely related to the competition with other plants because there were no macroalgae present, and the epiphytes cover did not exceed 30\% (Figure 9, Table 1). In this location, the low canopy cover value more likely related to the low density of seagrass. This difference in the factor that may associate with seagrass cover might provide an example that a seagrass meadow is a complex system in the coastal water.

As an ecosystem, its conditions also could be affected by abiotic factors such as salinity and nutrient level. The range of salinity in Ayau Island is between 33.5 and 35\% (Table 1). The value is still in accordance with the quality standards of salinity for marine biotas in the seagrass ecosystem waters is 33-34\%o (MNLH, 2004). Although the range is one per mile over the upper standard, this plant probably will not encounter any stress because seagrasses are generally euryhaline species. They might become a stress in the hyposaline $(<10 \%)$ or hypersaline $(>45 \%)$ conditions (Hogarth, 2007).

Nutrient level in seawater in the seagrass beds seems to be in the low-level condition, with phosphate $<0.1 \mathrm{mg} / \mathrm{l}$, and the nitrate is not detected with the kit that used in this study (Table 1). Although the phosphate level in this study could be higher than the quality standards of phosphate in marine water for marine biota, which is $0.015 \mathrm{mg} / \mathrm{l}$ for Indonesia and ASEAN standards (MNLH, 2004; ASEAN, 2008), it is still below the level for eutrophication to occur. In fact, it might have fallen to the range of $0.025-0.1 \mathrm{mg} / \mathrm{l}$, which stimulated the growth of plants without lead to eutrophication (Fadiran, et al., 2008). This also can explain the low cover percentage of macroalgae and epiphyte in this study (Table 1).

In general, the most extensive meadow was located in Dorehkar with more than 600 meters from the beach toward the sea. The length of the meadows seems to reflect the area of the meadows, with the largest meadows area also located in Dorehkar, supported by the fact that Kanober has the least length and the least area (Table 1). However, the correlation does not apply for Rutum and Abidon because Rutum has least meadow length than Abidon, but their meadows area are inversely ordered (Table 1). Nevertheless, with its relatively high value of seagrass composition, density, canopy cover, and area, seagrass meadow in Dorehkar can be considered having the best condition in this Ayau Islands.

\section{Conclusion}

Seagrass meadows in Ayau Islands have the characteristic of mixed seagrass meadow with two until five seagrasses forming the vegetation, with a variety of length and area size. In overall, there are five seagrass species from five seagrass bed in Ayau Island, which are Halodule pinifolia, Cymodocea rotundata, Enhalus acoroides, Thalassia hemprichii, and Halophila ovalis. The dominant species is $T$. hemprichii because this species is dominant in four locations and can be found in all locations. Based on the seagrass cover, the seagrass meadow in Reni, Rutum, and Dorehkar are in healthy status. Meanwhile, the seagrass meadow in Abidon and Kanober are in less health status.

As a baseline study, there are a lot of questions that cannot be answered in this study, such as why the number of species was lower than the neighbouring islands? or are the conditions remain the same from the past? or how are the projected conditions in the future? To answer those questions, further research is needed in this Ayau Islands.

\section{Acknowledgement}

The authors would like to thanks the Indonesian Institute of Sciences (LIPI) organizing the Nusa Manggala Expedition project with the COREMAP-CTI 2018 funding. Our gratitude also goes to Caleb Matuankotta, who helps us during the field sampling and laboratory analysis. We also thanks to all the participants in the Expedition $\left(3^{\text {rd }}\right.$ leg) and the crew of Research Vessel Baruna Jaya VIII for all their support and cooperation during the cruise, especially our media partner who provided us with beautiful images and documentations.

\section{References}

ASEAN, 2008. Marine Water Quality: Management Guidelines and Monitoring Manual. 1st ed. Jakarta: ASEAN Secretariat.

Ausal, M., Priosambodo, D., Litaay, M. \& Salam, M., 2017. Struktur komunitas padang lamun di perairan Kepulauan Waisai Kabupaten Raja Ampat Papua Barat. Jurnal IImu Alam dan Lingkungan, 8(15), pp. 29-37. [in Bahasa Indonesia]

Azkab, M. H., 1999. Pedoman Inventarisasi Lamun. Oseana, XXIV(1), pp. 1-16. [in Bahasa Indonesia]

Brazier, M. D., 1975. An Outline History of seagrass Communities. Paleontology, 18(4), pp. 681-702.

Dawes, C. J., 1981. Marine Botany. New York: Wiley Interscience.

de Boer, W. F., 2007. Seagrass-Sediment Interactions, Positive Feedbacks and Critical Thresholds for Occurrence: A Review. Hydrobiologia, Issue 591, pp. 5-24.

den Hartog, C., 1970. The Sea-Grasses of The World. Amsterdam: North Holland Publishing Company.

den Hartog, C. \& Kuo, J., 2006. Taxonomy and Biogeography of Seagrasses. In: A. W. D. Larkum, R. J. Orth \& C. M. Duarte (eds.). Seagrasses: Biology, Ecology and Conservation. s.l.: Springer, pp. 1-23.

Dewi, C. S. U., Subhan, B. \& Arafat, D., 2017. Keragaman, kerapatan dan penutupan lamun di perairan Pulau Biak, Papua. Depik, 6(2), pp. 122-127. [in Bahasa Indonesia]

Fadiran, A. O., Dlamini, S. C. \& Mavuso, A., 2008. A comparative study of the phosphate levels in some surface and ground water bodies of Szwaziland. Bull. Chem. Soc. Ethiop., 22(2), pp. 197-296. 
Fortes, M. D. et al., 2018. Seagrass in Southeast Asia: a review of status and knowledge gaps, and a road map for conservation. Botanica Marina, 61(3), p. 269-288.

Fourqurean, J. W. et al., 2012. Seagrass ecosystems as a globally significant carbon stock. Nature Geoscience, Volume 5, pp. 505-509.

Green, E. P., Mumby, P. J., Edwards, A. J. \& Clark, C. D., 2000. Remote Sensing Handbook for Tropical Coastal Management. Paris: UNESCO Pub.

Hafizt, M., Iswari, M. Y. \& Prayudha, B., 2017a. Assessment of Landsat-8 Classification Method for Benthic Habitat Mapping in Padaido Islands, Papua. Osenologi dan Lomnologi di Indonesia, 2(1), pp. 1-13.

Hafizt, M., Manessa, M. D. M., Adi, N. S. \& Prayudha, B., 2017b. Benthic Habitat Mapping by Combining Lyzenga's Optical Model and Relative Water Depth Model in Lintea Island, Southeast Sulawesi. IOP Conf. Ser. Earth Environ Sci, 98(1), p. 012037.

Hoek, F. et al., 2016. Struktur komunitas lamun di perairan distrik Salawati Utara Kabupaten Raja Ampat. Jurnal Airaha, 5(1), pp. 87-95. [in Bahasa Indonesia]

Hogarth, P. J., 2007. The Biology of Mangroves and Seagrasses. 2nd ed. New York: Oxford University Press.

Irawan, A., 2014. Struktur Komunitas Lamun di Teluk Weda, Pulau Halmahera, Maluku Utara. Jakarta, Ikatan Sarjana Oseanologi Indonesia, pp. 301-311. [in Bahasa Indonesia]

Kay, S., Hedley, J. D. \& Lavender, S., 2009. Sun Glint Correction of High and Low Spatial Resolution Images of Aquatic Scenes: a Review of Methods for Visible and Near-Infrared Wavelengths. Remote Sens., 1(4), pp. 697-730.

KMNLHRI, 2004. Kriteria Baku Kerusakan dan Pedoman Penentuan Status Padang LamuN. Jakarta: Kementerian Negara Lingkungan Hidup Republik Indonesia. [in Bahasa Indonesia]

Marshall, W., Schingler, R. \& al, e., 2017. Planet. [Online] Available at: https://www.planet.com/ [Accessed 6 February 2018].

McKenzie, L., Campbell, S. \& Roder, C., 2003. Seagrass-Watch: Manual for Mapping \& Monitoring Seagrass Resources by Community (Citizen) Volunteers. Cairns: Departement of Primary Industries Queensland, Northern Fisheries Centre.
Menez, E. G., Phillips, R. C. \& Calumpong, H. P., 1983. Seagrasses from the Philippines. Washington: Smithsonian Institution Press..

MNLH, 2004. Baku Mutu AIr Laut. Jakarta: Menteri Negara Lingkungan Hidup. [in Bahasa Indonesia]

Rahmawati, S. et al., 2019. BLUE CARBON IN SEAGRASS ECOSYSTEM: Guideline for the Assessment of Carbon Stock and Sequestration in Southeast Asia. Yogyakarta: Gadjahmada University Press.

Ramili, Y., Bengen, D., HH, M. \& Kawaroe, M., 2018. Struktur dan asosiasi jenis lamun di perairan Pulau-pulau Hiri, Ternate, Maitara dan Tidore, Maluku Utara. Jurnal IImu dan Teknologi Kelautan Tropis, 10(3), pp. 651-665. [in Bahasa Indonesia]

Sjafrie, N. D. M. et al., 2018. Status Padang Lamun Indonesia 2018. Ver.02 ed. Jakarta: Pusat Penelitian Oseanografi - LIPI. [in Bahasa Indonesia]

Supriyadi, I. H., Iswari, M. Y. \& Suyarso, 2018. KAJIAN AWAL KONDISI PADANG LAMUN DI PERAIRAN TIMUR INDONESIA. Segara, pp. 169-177. [in Bahasa Indonesia]

Susetiono, 2004. Fauna Padang Lamun Tanjung Merah Selat Lembeh. Jakarta: Pusat Penelitian Oseanografi - LIPI. [in Bahasa Indonesia]

\section{Declarations}

\section{Funding statement}

This research did not receive any specific grant from funding agencies in the public, commercial, or not-for-profit sectors.

\section{Conflict of interest}

The authors declare no conflict of interest.

\section{Additional information}

Reprints and permission information is available at https://mri.lipi.go.id

Publisher's Note: Indonesian Institute of Sciences remains neutral with regard to jurisdictional claims in published maps and institutional affiliations. 